\title{
Seroconversion analysis after habitual hepatitis $B$ vaccination scheme in patients with inflammatory bowel diseases
}

\author{
Isabella de Souza CUNHA, Tayná Cristina da SILVA, Éverson Fernando MALLUTA, \\ Bruno Lorenzo SCOLARO, Pablo Sebastian VELHO and Juliane STALL
}

Received: 15 November 2019 Accepted: 6 January 2020

\begin{abstract}
Background - Patients with inflammatory bowel disease (IBD) vaccinated for hepatitis B have a low success rate in achieving protective antibody levels. The main factors suggested for this are IBD itself and the use of immunosuppressive drugs. Objective - To evaluate the concentration of anti-HBs antibodies and to verify factors associated with the effectiveness of hepatitis B vaccination in patients with IBD. Methods - This is a prospective, consecutive, observational, descriptive and analytical, non-randomized, qualitative study that evaluated the levels of anti-HBs antibodies in IBD patients at the Interdisciplinary Inflammatory Bowel Disease Clinic of the Family and Community Health Unit of UNIVALI - Itajaí, Santa Catarina. Results - Thirty-six patients were vaccinated against hepatitis B virus (HBV), of which 29 were female. The average age was 46.2 years. Regarding the type of IBD, twenty-four patients had Crohn's disease and the duration of inflammatory bowel disease was 74 months. Fifteen patients were on concomitant immunosuppressive therapy. The effective response rate to HBV vaccine was $72.2 \%$, verified by anti-HBs titration $\geq 10$ UI/L. Statistical analysis revealed a negative response to vaccination in patients with Crohn's disease and immunosuppressive drugs. Conclusion - The success rate of HBV immunization in IBD patients is low compared to the general population. Type of disease and use of immunosuppressive drugs appear to influence the vaccine response.
\end{abstract}

HEADINGS - Inflammatory bowel diseases. Immunization. Hepatitis B. Crohn's disease. Ulcerative colitis. Seroconversion. Immunosuppressive agents.

\section{INTRODUCTION}

Inflammatory bowel diseases (IBD) are characterized by chronic and idiopathic inflammatory bowel disorders, being represented by ulcerative colitis (UC) and Crohn's disease (CD). Both have similar clinical-pathological presentations that need to be differentiated by clinical, endoscopic, histological and radiological methods ${ }^{(1,2)}$.

IBDs have no cure, but we can achieve remission or inactivity of the disease with the use of immunosuppressive drugs, biological agents and corticoids ${ }^{(2,3)}$.

Patients with IBD are at high risk for hepatitis B virus (HBV) infection due to blood transfusions, invasive surgical procedures and endoscopic procedures ${ }^{(4)}$.

Those with IBD and HBV infection, especially those on immunosuppressive therapy, are more likely to have hepatitis reactivation, which may be associated with a worse prognosis, resulting in fulminant liver failure and death ${ }^{(5)}$.

Studies show that few IBD patients who need HBV vaccination are actually vaccinated and given adequate immunization. The prevalence of hepatitis B immunity verified by titration of antiHBs antibodies is low in individuals with IBD, ranging from $12 \%$ to $77 \%$ of optimal immunization against the virus ${ }^{(6,7)}$.

Hepatitis B vaccination is a proven and well-established strategy for disease prevention. In addition to being safe and effective, HBV vaccine in the general population confers immunity to over $90 \%$ of vaccinated individuals ${ }^{(8)}$. The standard vaccination schedule includes three doses of $1 \mathrm{~mL}, 20 \mathrm{mg}$ recombinant HBsAg administered at 0,1 and 6 months $^{(9)}$.

The success rate of hepatitis B immunization in IBD patients, verified by protective antibody levels with the usual vaccination schedule, is very low compared to the general population. Although several factors have been suggested, the disease itself and the use of immunosuppressants are considered the main reasons ${ }^{(10,11)}$.

The objectives of this study are to evaluate anti-HBs antibody concentration and to verify factors associated with vaccination effectiveness in hepatitis B vaccinated IBD patients at the Interdisciplinary Inflammatory Bowel Disease Clinic of the Family and Community Health Unit of UNIVALI - Itajaí, Santa Catarina (SC).

\section{METHODS}

\section{Study design}

This is a prospective, consecutive, observational, descriptive and analytical, non-randomized, qualitative study. This study was approved by the Research Ethics Committee of the University of Vale do Itajaí, under the number: 2,848,867 and follows Resolution 466/2012 of the National Health Council of the Ministry of Health (Brazil), which deals with the Code of Ethics for Human Research. 


\section{Studied population}

The study was conducted at the Interdisciplinary Inflammatory Bowel Disease Clinic of the Family and Community Health Unit of UNIVALI - Itajaí, from August 2018 to November 2019. Patients over 18 years old with a confirmed diagnosis of IBD (established by clinical, radiographic, endoscopic and standard histological criteria) and vaccinated for hepatitis B with usual vaccination schedule were evaluated.

\section{Methodology}

From August 2018 to November 2019 data were collected from 36 patients with IBD. The patients were approached at the Interdisciplinary Inflammatory Bowel Disease Clinic, where the project was presented, and therefore the patients were invited to participate in the research project. After informed consent, demographic and disease-related data were collected through medical records. Thereby, the presence or absence of hepatitis B serology was verified. Patients who did not have or had low anti-HBs antibody titles $(<10 \mathrm{UI} / \mathrm{L})$ were referred for vaccination, as routinely defined by the service. Anti-HBs titles were measured one to three months after the last dose of the vaccine, such examination was requested by the attending physician.

Anti-HBs titles were measured one to three months after the last dose of the vaccine. This difference of time of anti-HBS measurement from each patient was not included in the statistical analysis.

\section{Variables analyzed}

Demographic data were analyzed, such as: age; sex; type of IBD (Crohn's disease or ulcerative colitis), time of IBD progression, drug treatment (immunomodulators, anti-TNF, corticosteroids and aminosalicylates) before or concomitantly with vaccine administration, disease activity index using CDAI for Crohn's disease and MAYO for ulcerative colitis, seropositivity or negativity following the last dose of hepatitis surface antigen (anti-HBs) antibody vaccine.

\section{Statistical analysis}

A descriptive analysis was performed to characterize the sample by calculating mean and standard deviation or median and quartiles for quantitative variables and frequencies and proportions for qualitative variables.

Associations between categorical variables were studied using chi-square test and Fisher's exact test, when appropriate. For continuous variables, the Mann-Whitney test was used.

The collected data were entered and tabulated directly in the Microsoft Excel ${ }^{\circledR} 2016$ program.

\section{RESULTS}

Thirty-six patients were vaccinated against HBV, of which $29(80.5 \%)$ were of the female sex and $7(19.5 \%)$ were male. The average age was $46.2 \pm 13$ years. Regarding the type of inflammatory bowel disease, $24(66.6 \%)$ patients had Crohn's disease and 12 (33.4\%) had ulcerative colitis. The duration of inflammatory bowel disease found was 74 months. Regarding the disease activity index during vaccination, $35(97.2 \%)$ patients were in remission and only $1(2.8 \%)$ was in activity.

Fifteen $(41.6 \%)$ patients were on immunosuppressive therapy concomitant with the vaccination. The immunosuppressive drugs present, either alone or in combined therapy, were azathioprine, used by $10(20.8 \%)$ patients, anti-TNF, used by $6(12.5 \%)$ patients corticosteroids, used by $4(8.3 \%)$ patients and methotrexate, used by only $1(2.1 \%)$ patient. In our study, the immunosuppressive dose consisted of: azathioprine 2 at $2.5 \mathrm{mg} / \mathrm{kg}$ orally and methotrexate $25 \mathrm{mg}$ IM. The doses of anti-TNF drugs were: infliximab $5 \mathrm{mg} /$ $\mathrm{kg}$ IV, adalimumab $40 \mathrm{mg}$ subcutaneous. However, no statistical analysis was performed correlating the drug doses.

The non-immunosuppressive drug present during vaccination, either alone or in combination therapy, was mesalazine in 14 $(29.2 \%)$ patients. About $13(27.1 \%)$ patients were without medication at the time of vaccination.

Regarding the use of monotherapy or combined therapy, $13(56.5 \%)$ patients were on monotherapy and $10(43.5 \%)$ were on combined therapy. Towards the type of monotherapy, eight patients were on mesalazine, four patients were on azathioprine and two were on anti-TNF. Regarding drug combinations, three patients were using the mesalazine + corticosteroid combo, three were using azathioprine + anti-TNF, two were using mesalazine + azathioprine, one was using mesalazine + methotrexate and one was on azathioprine + anti-TNF + corticosteroid use. TABLE 1 discusses the pharmacological therapy.

TABLE 1. Pharmacological therapy received by the patients at the time of vaccination $(n=23)$.

Patients $(\mathrm{n}=23)$

Monotherapy

$\begin{array}{ll}\text { Mesalazine } & 8 \\ \text { Azathioprine } & 3 \\ \text { Anti-TNF } & 2 \\ \text { Combined therapy } & 3 \\ \text { Mesalazine + Corticosteroids } & 3 \\ \text { Azathioprine + Anti-TNF } & 2 \\ \text { Mesalazine + Azathioprine } & 1 \\ \text { Mesalazine + Metotrexate } & 1 \\ \text { Azathioprine + Anti-TNF + Corticosteroids } & \end{array}$

The effective response rate to the $\mathrm{HBV}$ vaccine was analyzed considering the anti-HBs titres as cut-off point $\geq 10 \mathrm{UI} / \mathrm{L}$. Ten $(27.8 \%)$ patients did not respond to vaccination (anti-HBs $<10$ $\mathrm{UI} / \mathrm{L}$ ) and $26(72.2 \%)$ patients responded to hepatitis $\mathrm{B}$ vaccination. Of these, $8(22.2 \%)$ patients had anti-HBs titrations between 10-99 IU/L, while $18(50 \%)$ had anti-HBs $\geq 100 \mathrm{IU} / \mathrm{L}$.

Statistical analysis revealed that the response rate to HBV vaccination is lower in patients receiving concomitant immunosuppressive therapy, using the anti-HBs $\geq 10 \mathrm{IU} / \mathrm{L}(53.3 \%$ vs $85.7 \%$, $P=0.032$ ). When using the anti-HBs cut-off point $\geq 100 \mathrm{IU} / \mathrm{L}$, no statistical significance was demonstrated $(33.3 \%$ vs $61.9 \%, P=0.091$ ). According to the analysis, patients without immunosuppressive drugs are three times more likely to respond positively to hepatitis $B$ vaccination (relative risk $=3.27$ ).

Another variable with statistical relevance in response to HBV vaccine was the type of disease, in which Crohn's disease patients had reduced response to vaccination $(P=0.008)$.

TABLE 2 shows the results discussed above. 
TABLE 2. Correlation between clinical and demographic variables and response to hepatitis $B$ vaccination $(n=36)$.

\begin{tabular}{|c|c|c|c|}
\hline & \multicolumn{2}{|c|}{ Anti-HBS } & \multirow{2}{*}{$\frac{\text { chi-square }}{P}$} \\
\hline & $<10$ & $>10$ & \\
\hline Gender & & & 0.370 \\
\hline Female & $9(31.0)$ & $20(69)$ & \\
\hline Male & $1(14.3)$ & $6(85.7)$ & \\
\hline Age & & & 0.212 \\
\hline Up to 40 years old & $2(15.4)$ & $11(84.6)$ & \\
\hline Over 40 years old & $8(34.8)$ & $15(65.2)$ & \\
\hline Inflammatory bowel disease & & & 0.008 \\
\hline Crohn's disease & $10(41.7)$ & $14(58.3)$ & \\
\hline Ulcerative colitis & $0(0)$ & $12(100)$ & \\
\hline Time of IBD progression & & & 0.899 \\
\hline Up to 5 years & $4(26.7)$ & $11(73.3)$ & \\
\hline Over 5 years & $6(28.6)$ & $15(71.4)$ & \\
\hline Treatment & & & 0.032 \\
\hline $\begin{array}{l}\text { With immunossuppressive } \\
\text { treatment }\end{array}$ & $7(46.7)$ & $8(53,3)$ & \\
\hline $\begin{array}{l}\text { Without } \\
\text { immunossuppressive } \\
\text { treatment }\end{array}$ & $3(14.3)$ & $18(85.7)$ & \\
\hline Disease activity & & & 0.529 \\
\hline Remission & $10(28.6)$ & $25(71.4)$ & \\
\hline In activity & $0(0)$ & $1(100)$ & \\
\hline
\end{tabular}

Immunomodulatory and biological drugs have revolutionized the prognosis of patients with IBD, reducing the onset of complications, the number of surgical interventions and hospital stay, and increase quality of life of these patients. However, these medicines are not without complications, one of them being the potential increase in the risk of infections. In this susceptible group of patients, all measures that reduce the risk of infection should be applied ${ }^{(12)}$. Therefore, a history of vaccination should be checked to reduce the risk of preventable infections such as influenza, pneumococcal disease, chickenpox, hepatitis $\mathrm{B}$, and tetanus $\mathrm{s}^{(13)}$. The use of immunosuppressive agents may interfere with the vaccine response, and vaccination is recommended when possible at diagnosis ${ }^{(14)}$.

The currently recommended vaccines in IBD patients are diphtheria, tetanus, inactivated polio, pertussis, hepatitis B, pneumococcus, influenza, human papillomavirus, hepatitis A, meningococcal disease, and Haemophilus influenza $\mathrm{B}^{(15)}$.

The hepatitis B vaccination rate is known to be low in IBD patients. In one American study, of the 75 patients with risk factors for HBV infection, only 23 had received adequate immunization ${ }^{(16)}$. Therefore, patients need to be informed about the importance of vaccination, as well as the need to verify if the vaccine was performed properly.

In our research, demographic data revealed the predominance of women, with an average age of 46 years, which corroborates with other studies, indicating a representative sample of the population ${ }^{(17)}$. Despite our reduced sample size with only 36 patients, we obtained statistically relevant variables, which will be discussed later.
According to the study by Vida et al., $65.9 \%$ of the patients analyzed did not have adequate response to the vaccine, being the only factor involved in the negative response their ages, thus younger patients showed higher response to the vaccination ${ }^{(12)}$. In our study, there was no significance in vaccine response when comparing the age of patients, which is consistent with other studies ${ }^{(7,11)}$.

In our study, the mean time of IBD progression was 6.2 years, which was not statistically significant when related to the response to HBV vaccination. Only one study, by Sempere et al., found significance of this variable with negative response to vaccination due to long-term progression of IBD $^{(11)}$.

Regarding the disease activity index, our study showed that 35 patients were in remission and only one in IBD activity. Such variable was not relevant. A study by Altunoz et al. demonstrated worse response to $\mathrm{HBV}$ vaccination in patients with active disease ${ }^{(7)}$.

According to Chevaux et al., effective vaccination was detected in $48.9 \%$ of their patients. In this study, patients with UC were significantly more responsive to effective vaccination than patients with $\mathrm{CD}$, which is reinforced by the results presented by our study $(100 \% \text { UC vs } 58.3 \% \text { DC, } P=0.008)^{(18)}$. In addition, Sempere et al. also showed relevance regarding to Crohn's disease for a negative response to vaccination, however, specifying the place of involvement of the IBD, in this case ileal $\mathrm{CD}^{(11)}$. This can be explained by the frequent use of immunosuppressive drugs in this pathology ${ }^{(16)}$. So far, the Brazilian particularity is that, according to the Crohn's Disease Clinical Protocol and Therapeutic Guidelines, combined immunosuppressive therapy is available, while it's not in ulcerative colitis $^{(19)}$. Therefore, CD patients have easier access to superior immunosuppression when compared to the second part.

Regarding the vaccine response, our study had a response rate of $72.2 \%$, which is lower compared to the general population, as $90 \%$ of healthy adult individuals develop protective antibodies after vaccination ${ }^{(8)}$. The response rate vaccine found in our study is similar to that found by Altunoz et al. (77\%) and much higher than studies such as Sempere et al. (47.6\%), Vida et al. (34.1\%) and Loras et al. (12\%), where was used the standard HBV vaccination schedule (HBsAg $20 \mathrm{mg}$ at 0,1 and 6 months) and anti-HBs antibody cut-off point $\geq 10$ IU/L ${ }^{(6,7,11,12)}$. In a study by Gisbert et al., which used the accelerated double-dose regimen ( $40 \mathrm{mg} \mathrm{HBsAg}$ at 0,1 and 2 months), the response was $59 \%(20)$.

Immunosuppressed patients are defined as those undergoing corticosteroid treatment (prednisone $20 \mathrm{mg} /$ day or $2 \mathrm{mg} / \mathrm{kg} /$ day if $<10 \mathrm{~kg}$, for two weeks or more and within three months after discontinuation), patients on ongoing treatment with effective doses of thiopurines (mercaptopurine/azathioprine) or recent discontinuation in the previous three months, patients receiving methotrexate or recent discontinuation in the previous three months, patients receiving anti-TNF (infliximab, adalimumab, certolizumab and natalizumab) or recent discontinuation in the previous three months and patients with significant protein-energy malnutrition $^{(21)}$. We performed the statistical analysis correlating two groups: patients with immunosuppressive therapy and patients without immunosuppressive therapy. Patients with immunosuppressive therapy included those taking corticoidsteroid, azathioprine, methotrexate, adalimumab and infliximab. Patients without immunosuppressive therapy included those taking mesalazine or who were off medication at the time of vaccination. It was not possible to perform an analysis isolating each class of medicines by the reduced sampling.

Our study demonstrated that the response rate to HBV vaccina- 
tion was lower in patients receiving concomitant immunosuppressive therapy at the time of vaccination when using the anti-HBs cut-off point $\geq 10 \mathrm{UI} / \mathrm{L}(53.3 \%$ vs $85.7 \%, P=0.032)$. Altunoz et al. demonstrated that the group classified as immunosuppressed had a lower response rate to $\mathrm{HBV}$ vaccination than patients without immunosuppressive drugs, which corroborates with our study ${ }^{(7)}$. Similarly, Gisbert et al. also found worse vaccine response in patients using any immunosuppressant ${ }^{(20)}$. Cekic et al. found that patients on corticosteroids and azathioprine in combination with anti-TNF had lower response to HBV vaccination ${ }^{(22)}$. Sempere et al. also demonstrated worse response to vaccination in patients on corticosteroids therapy ${ }^{(11)}$.

For a general population, the Center for Disease Control recommends measuring the titration of anti-HBs one to two months after vaccination ${ }^{(8)}$. However, there is no consensus on the optimal time to check vaccine response in IBD patients, especially immunosuppressed ones. In our study, the vaccine response was collected one to three months after the last vaccination dose. Such interval is a consensus between studies, such as Gisbert and Sempere ${ }^{(11,20)}$. The relationship between the time the vaccination success was evaluated and effective response rate was not analysed.

The rate of protection by titrating anti-HBs antibodies is under debate. Anti-HBs titers $\geq 10 \mathrm{UI} / \mathrm{L}$ are considered protective against hepatitis $\mathrm{B}$, but HBV infection has been documented in immunocompromised persons who do not maintain levels of anti-HBs $\geq 10$ $\mathrm{UI} / \mathrm{L}^{(23)}$. Therefore, some authors have suggested that anti-HBs target concentration in immunocompromised patients is $\geq 100$ $\mathrm{UI} / \mathrm{L}^{(24,25)}$. Based on this evidence, in the UK the seroprotection against $\mathrm{HBV}$ infection has recently been redefined to $\geq 100 \mathrm{UI} / \mathrm{L}^{(26)}$. In such a way, using this cut-off point, half of the patients in our study would not achieve optimal hepatitis B immunity and we would see a $22.2 \%$ reduction in immunized patients. Although, considering anti-HBs $\geq 10 \mathrm{UI} / \mathrm{L}$ as a successful response to vaccination, $72.2 \%$ of patients had seroconversion.

According to the Ministry of Health of Brazil, there are individual and specific situations for the adoption of different regimen and dosage for administration of the HBV vaccine. Patients with chronic renal disease, polytransfused, and hemophilic are included in the risk group category because they have lower antibody production. For them, twice the volume of hepatitis B vaccine dose is recommended. Although patients with IBD are not included in this classification, their insertion would be beneficial due to the low success rate in achieving protective levels of hepatitis B antibodies.

Larger studies are needed to clarify further factors involved in a lower response rate to HBV vaccination in IBD patients. In addition, new protocols are needed to define a targeted immunization schedule for IBD patients, such as: double-dose vaccination; anti-HBs antibody cut-off point $\geq 100 \mathrm{UI} / \mathrm{L}$; vaccination prior to the use of immunosuppressants.

\section{CONCLUSION}

The success rate in obtaining an effective immune response with standard HBV vaccination protocols in patients with IBD is low, the type of disease and use of immunosuppressive drugs are the main factors influencing vaccine response. The main contribution of our study is to make patients aware of their own immunization status and the importance of adequate immunization, especially in the immunosuppressed population.

\section{Authors' contribution}

Cunha IS, Silva TC: data collection, research execution, text writing, statistical analysis. Malluta EF, Scolaro BL, Velho PS: research execution, text writing. Stall J: text writing.

\section{Orcid}

Isabella de Souza Cunha: 0000-0001-9358-8373.

Tayná Cristina da Silva: 0000-0002-9567-4678.

Éverson Fernando Malluta: 0000-0001-6554-6280.

Bruno Lorenzo Scolaro: 0000-0001-6277-7075.

Pablo Sebastian Velho: 0000-0003-0502-1743.

Juliane Stall: 0000-0002-9664-4673.

Cunha IS, Silva TC, Malluta EF, Scolaro BL, Velho PS, Stall J. Análise da soroconversão após esquema habitual de vacinação contra hepatite B em pacientes com doenças inflamatórias intestinais. Arq Gastroenterol. 2020;57(1):69-73.

RESUMO - Contexto - Os pacientes com doenças inflamatórias intestinais (DII) vacinados para hepatite B possuem baixa taxa de sucesso em alcançar níveis protetores de anticorpos. Os principais fatores sugeridos para isso são a própria DII e o uso de medicamentos imunossupressores. Objetivo Avaliar a titulação de anticorpos anti-HBs e verificar fatores associados a efetividade da vacinação contra hepatite B em pacientes com DII. Métodos - Trata-se de um estudo prospectivo e consecutivo, de caráter observacional, descritivo e analítico, não-randomizado, qualiquantitativo, que avaliou a titulação de anticorpos anti-HBs em pacientes portadores de DII no Ambulatório Interdisciplinar de Doença Inflamatória Intestinal da Unidade de Saúde da Família e Comunitária da UNIVALI - Itajaí, Santa Catarina. Resultados - Trinta e seis pacientes foram vacinados contra o vírus da hepatite B (VHB), destes, 29 eram do sexo feminino. A média de idade foi de 46,2 anos. Em relação ao tipo de DII, 24 pacientes eram portadores de doença de Crohn e o tempo médio de doença inflamatória intestinal encontrado foi de 74 meses. Quinze pacientes estavam em uso de terapia imunossupressora concomitante à vacinação. A taxa de resposta à vacina contra o VHB foi de $72,2 \%$, verificada através de titulação de anti-HBs $\geq 10$ UI/L. A análise estatística revelou uma resposta negativa à vacinação em pacientes em uso de medicamentos imunossupressores e portadores de doença de Crohn. Conclusão - A taxa de sucesso na imunização contra o VHB em pacientes com DII é baixo quando comparado à população em geral. Tipo de doença e uso de medicamentos imunossupressores parecem desempenhar influência na resposta vacinal.

DESCRITORES - Doenças inflamatórias intestinais. Imunização. Hepatite B. Doença de Crohn. Colite ulcerativa. Soroconversão. Imunossupressores. 


\section{REFERENCES}

1. Bernstein CN, Fried M, Krabshuis JH, Cohen H, Eliakim R, Fedail S, et al. World Gastroenterology Organization Practice Guidelines for the diagnosis and management of IBD in 2010. Inflamm Bowel Dis. 2010;16:112-24.

2. Sairenji T, Kimberly LC, David VE. An Update on Inflammatory Bowel Disease. Prim care. 2017;44:673-92.

3. Dave M, Purohit T, Razonable R, Loftus Jr EV. Opportunistic infections due to inflammatory bowel disease therapy. Inflamm Bowel Dis. 2013;20:196-212.

4. Tolentino YFM, Fogaça HS, Zaltman C, Ximenes LLL, Coelho, HSM. Hepatitis $\mathrm{B}$ virus prevalence and transmission risk factors in inflammatory bowel disease patients at Clementino Fraga Filho university hospital. World J Gastroenterol. 2008; $14: 3201$.

5. Hou JK, Velayos F, Terrault N, Mahadevan U. Viral hepatitis and inflammatory bowel disease. Inflamm Bowel Dis. 2010;16:925-32.

6. Loras C, Saro C, Gonzalez-Huix, F, Mínguez, M, Merino, O, Gisbert, J. P, et al. Prevalence and factors related to hepatitis $\mathrm{B}$ and $\mathrm{C}$ in inflammatory bowel disease patients in Spain: a nationwide, multicenter study. Am J Gastroenterol. 2009; 104:57.

7. Altunöz ME, Şenates, E, Yeşil A, Çalhan T, Övünç AOK. Patients with inflammatory bowel disease have a lower response rate to $\mathrm{HBV}$ vaccination compared to controls. Dig Dis Sci. 2012;57:1039-44.

8. $\mathrm{CDC}-\mathrm{Center}$ for Disease Control and Prevention. Epidemiology and Prevention of Vaccine-Preventable Diseases. (13th ed.). Washington DC: Public Health Foundation. 2017.

9. Brasil. Ministério da Saúde. Manual de normas e procedimentos para vacinação. Brasília: Ministério da Saúde. 2014.

10. Magro F, Abreu C. Immunisations in Crohn's disease: who? why? what? when? Best Pract Res Clin Gastroenterol. 2014;28:485-96.

11. Sempere L, Almenta I, Barrenengoa J, Gutiérrez A, Villanueva CO, de-Madaria E, et al. Factors predicting response to hepatitis B vaccination in patients with inflammatory bowel disease. Vaccine. 2013;31:3065-71.

12. Pérez LV, Camacho FG, Sánchez VG, Flores EMI, Molina LC, Ruiz AC, et al. Eficacia de la vacuna contra el virus de la hepatitis B en pacientes con enfermedad inflamatoria intestinal. Med Clin. 2009;132:331-5.

13. Harper SA, Fukuda K, Uyeki TM, Cox NJ, Bridges CB. Prevention and control of influenza: recommendations of the Advisory Committee on Immunization Practices (ACIP). Morb Mortal Wkly Rep. 2005;54:1-41.

14. Nguyen GC, Devlin SM, Afif W, Bressler B, Gruchy SE, Kaplan GG, et al. Defining quality indicators for best-practice management of inflammatory bowel disease in Canada. Can J Gastroenterol Hepatol. 2014;28:275-85.
15. Viget N, Vernier-Massouille G, Salmon-Ceron D, Yazdanpanah Y, Colombel JF. Opportunistic infections in patients with inflammatory bowel disease: prevention and diagnosis. Gut. 2008;57:549-58.

16. Melmed G, Ippoliti AF, Papadakis KA, Tran TT, Birt JL, Lee SK, et al. Patients with inflammatory bowel disease are at risk for vaccine-preventable illnesses. Am J Gastroenterol. 2006;101:1834.

17. Strasse KL, Jamur CM, Marques J, Kim MSM, Petterle RR, Amarante HMBDS. Immunization status of patients with inflammatory bowel disease. Arq Gastroenterol. 2019;56:124-30.

18. Chevaux JB, Nani A, Oussalah A, Venard V, Bensenane M, Belle A, et al. Prevalence of hepatitis B and $\mathrm{C}$ and risk factors for nonvaccination in inflammatory bowel disease patients in Northeast France. Inflamm Bowel Dis. 2009;16: 916-24.

19. Brasil. Ministério da Saúde. Protocolo Clínico e Diretrizes Terapêuticas - Doença de Crohn. Brasília: Ministério da Saúde. 2017.

20. Gisbert JP, Menchén L, García-Sánchez V, Marín I, Villagrasa JR, Chaparro M. Comparison of the effectiveness of two protocols for vaccination (standard and double dosage) against hepatitis B virus in patients with inflammatory bowel disease. Alimen Pharmac \& Therap. 2012;35:1379-85.

21. Sands BE, Cuffari C, Katz J, Kugathasan S, Onken J, Vitek C, Orenstein W. Guidelines for immunizations in patients with inflammatory bowel disease. Inflamm Bowel Dis. 2004;10:677-92.

22. Cekic C, Aslan F, Kirci A, Gümüs ZZ, Arabul M, Yüksel ES, et al. Evaluation of factors associated with response to hepatitis $\mathrm{B}$ vaccination in patients with inflammatory bowel disease. Medicine. 2015;94:22.

23. Stevens CE, Alter HJ, Taylor PE, Zang EA, Harley EJ, Szmuness W. Hepatitis B vaccine in patients receiving hemodialysis. Immunogenicity and efficacy. N Engl J Med. 1984;311:496-501.

24. Gisbert, JP, Chaparro, M, Esteve, M. Prevention and management of hepatitis $\mathrm{B}$ and $\mathrm{C}$ infection in patients with inflammatory bowel disease. Alimen pharmac \& therap. 2011;33:619-33.

25. Zuckerman JN, Sabin C, Fiona MC, Williams A, Zuckerman AJ. Immune response to a new hepatitis $\mathrm{B}$ vaccine in healthcare workers who had not responded to standard vaccine: randomised double blind dose-response study. BMJ. 1997;314:29.

26. Salisbury D, Ramsay M, Noakes K. Immunisation against infectious diseases. T Stat Offic. 2006. 